\title{
Surface properties in S500MC steel with zinc coating
}

\author{
Agata Dudek ${ }^{1, *}$, Katarzyna Strzelczak ${ }^{1}$, and Barbara Lisiecka ${ }^{1}$ \\ ${ }^{1}$ Institute of Material Engineering, Faculty of Processing Engineering and Materials Technology, \\ Czestochowa University of Technology, Armii Krajowej 19, 42-200 Czestochowa, Poland
}

\begin{abstract}
Zinc metal has a number of characteristics that make it a wellsuited corrosion protective coating for iron and steel products. Due to the zinc's corrosion resistance on most environments, it provides an effective protective coating on many products and in many exposure conditions. Zinc, like all metals, corrodes when exposed to the atmosphere. However, because of its ability to form dense, adherent corrosion byproducts, the rate of corrosion is considerably lower than ferrous materials (10 to 100 times slower depending on the environment). In this study, a comparison of two series of specimens of alkaline electrochemical galvanizing steel S500MC (HSLA) was made. One series of samples was not stripped of the oxide layer from the substrate. The analysis was made using optical microscopy, electron scanning microscopy and X-ray diffraction.
\end{abstract}

\section{Introduction}

Zinc- and zinc-alloy-coated steel products are finding numerous applications in various branches of industry $[1,2]$ as shown in Table 1 .

Table 1. Applications of zinc-coated steel products [3].

\begin{tabular}{|c|l|}
\hline Coating & \multicolumn{1}{|c|}{ Application } \\
\hline \multicolumn{2}{|c|}{ Coatings by continuous process } \\
\hline $\mathrm{Zn}-\mathrm{Fe}$ & Autobody panels and structural components \\
\hline $\mathrm{Zn}$ and Zn-Al & $\begin{array}{l}\text { Roofing, siding, doors, culvert, housing, } \\
\text { autobody panels and structural components }\end{array}$ \\
\hline $\mathrm{Zn}-\mathrm{Ni}$ & $\begin{array}{l}\text { Autobody panels, housings, appliances, } \\
\text { fasteners }\end{array}$ \\
\hline $\mathrm{Zn}-\mathrm{Co}$ & Automotive small parts and fasteners \\
\hline \multicolumn{2}{|c|}{ Batch galvanized coatings } \\
\hline \multirow{2n}{*}{$\begin{array}{l}\text { Structural steel for power-generating plants, } \\
\text { petrochemical facilities, heat exchangers, } \\
\text { cooling coils, bridge structural members, } \\
\text { culverts, marine pilings, rails, reinforcing } \\
\text { steel for concrete structures }\end{array}$} \\
\hline
\end{tabular}

* Corresponding author: dudek.agata@,wip.pcz.pl 
The prevalence of zinc coatings resulting from the availability, low price, good protective and decorative properties of the metal. Zinc, as a more electronegative metal than iron, forms anodic coatings on steel (Fig. 1). In moist air, corrosion products formed on the surface create a tight layer that insulates the substrate from the environment [4-5]. As additional corrosion protection of zinc coatings, the production of chromate or phosphate layers on them, and the lastly recommended chromite ones are used [6-8].
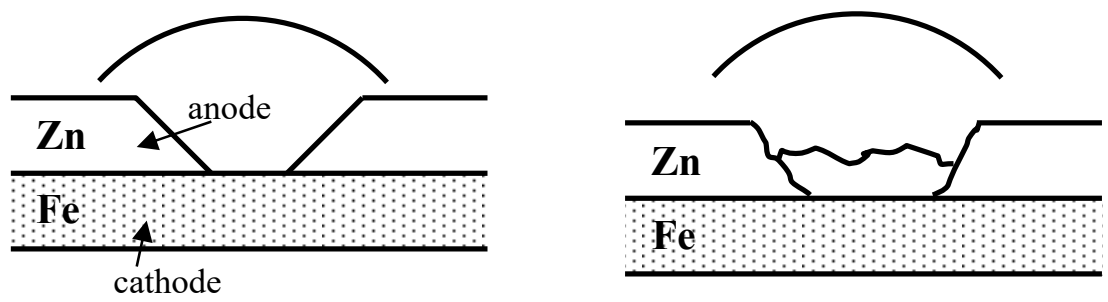

Fig. 1. Diagram of corrosion of anodic coatings.

Several types of galvanic baths are used for galvanizing, depending on the required properties and application of the coating. These are acidic, weak acidic and alkaline baths cyanide and non-cyanide. New generation galvanizing is based on alkaline non-cyanide electrolytes [9].

Galvanic coatings should be characterized by good adhesion of the coating to the substrate, external appearance, fine-crystalline structure, tightness and appropriate minimum coating thickness for given conditions of use. The main factors affecting the quality of the galvanic coating are: concentration and intensity of electrolyte mixing, temperature, presence of surfactants, cathodic current density, type of electrolyte, the property of the metal on which the coating is deposited [10-11].

In this study S500MC (HSLA) was subjected to alkaline electrochemical galvanizing. The S500MC is a hot rolled, high-strength low-alloy steel (HSLA) characterized by reproducible quality and excellent engineering properties. The well-balanced chemical composition together with the fine-grained microstructure created in the thermomechanical rolling process creates steel with the highest class of mechanical properties and cold formability. Typical applications of S500MC include a wide range of steel components and structures, e.g. truck chassis and crane booms [12-17].

\section{Material and Methods}

The research was carried out for specimens of alkaline electrochemical galvanizing steel S500MC (HSLA). As additional corrosion protection of zinc coatings, the production of chromate layer on steel was used. Compositional specification of S500MC steel is included in Table 2.

Table 2. Chemical composition of S500MC steel (HSLA) (in wt. \%).

\begin{tabular}{|c|c|c|c|c|c|c|c|c|}
\hline $\begin{array}{c}\mathrm{Mn} \\
(\max \%)\end{array}$ & $\begin{array}{c}\mathrm{C} \\
(\max \%)\end{array}$ & $\begin{array}{c}\mathrm{Si} \\
(\max \%)\end{array}$ & $\begin{array}{c}\mathrm{P} \\
(\max \%)\end{array}$ & $\begin{array}{c}\mathrm{S} \\
(\max \%)\end{array}$ & $\begin{array}{c}\mathrm{Al} \\
(\max \%)\end{array}$ & $\begin{array}{c}\mathrm{Nb} \\
(\max \%)\end{array}$ & $\begin{array}{c}\mathrm{V} \\
(\max \%)\end{array}$ & $\begin{array}{c}\mathrm{Ti} \\
(\max \%)\end{array}$ \\
\hline 1.60 & 0.10 & 0.21 & 0.025 & 0.010 & 0.015 & 0.09 & 0.20 & 0.15 \\
\hline
\end{tabular}

Two series of samples were prepared, which differed in the way of preparing the surface before the zinc coating process. Both series were degreased in acetone, left to dry at room temperature and washed with de-ionized water. The thickness of the zinc layer of each sample series was $10 \mu \mathrm{m}$. 
Analysis of microstructure of specimens after galvanizing process was carried out using microscope OLYMPUS GX41 with stereo digital image recording and electron scanning microscope Jeol JSM-6610LV. Identification of phase composition of zinc coatings was made using X-ray diffractometer Seifert 3003 TT with cobalt lamp with characteristic radiation wavelength of $\lambda_{\text {cok } \alpha}=0.17902 \mathrm{~nm}$.

\section{Results and Discussion}

The microstructure were observed using the metallographic sections etched with Nital. Figure 2 illustrates the results obtained for the zinc coating by the optical microscope Olympus GX41. In Figure 2a the sample has a partially recrystallized ferrite structure and shows effects of cold work after plastic working resulting in elongated ferrite grains with irregular borders. While the sample in the Figure $2 \mathrm{~b}$ was characterized by the presence of numerous polygonal ferrite grains, but also by the carbide phase disclosed in the pearlite. For this series of samples, a full recrystallization of the structure is noticeable. Probably after the annealing process, the surface of the sample with poor quality of steel substrate (Fig. 2b) was characterized by the presence of an oxide layer that had not been thoroughly removed before zinc coating.

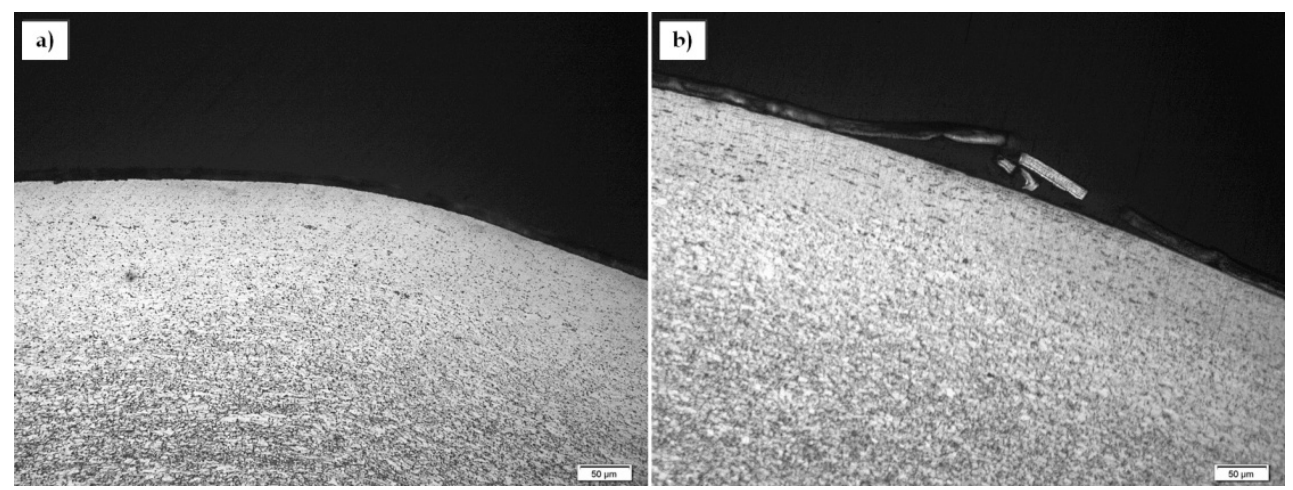

Fig. 2. Microstructure of zinc coating with: a) good, b) poor quality of the steel substrate.

The zinc coating deposited using the electrochemical method on the S500MC steel had thickness of around $10 \mu \mathrm{m}$. Figure 3 presents the cross-section of zinc coating microstructure obtained from the scanning microscope Jeol JSM-6610LV.
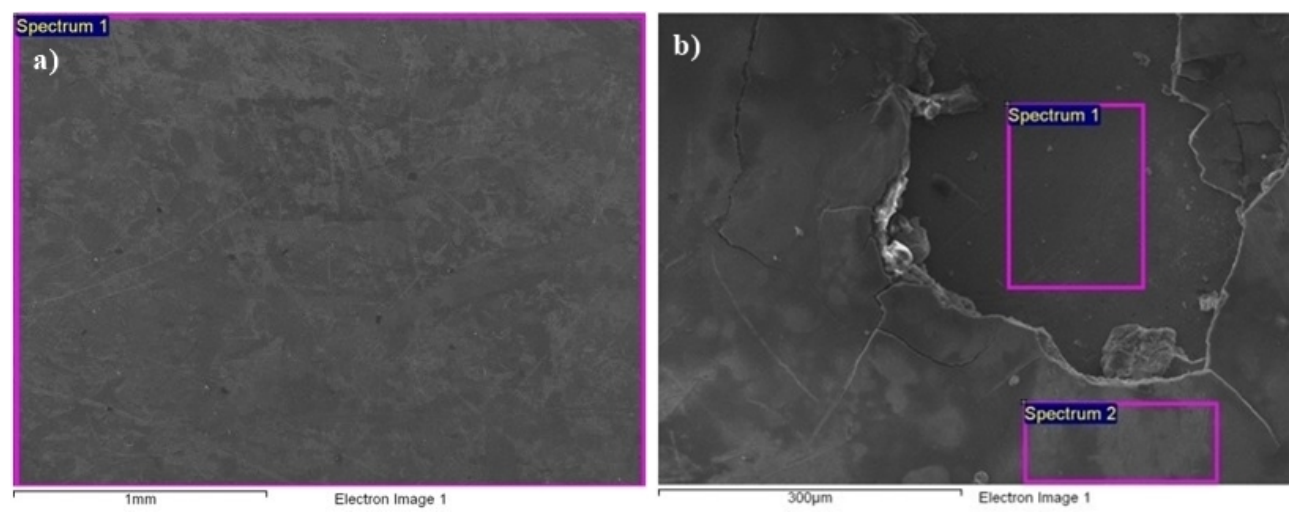

Fig. 3. Microstructure of the cross-section of zinc coating with: a) good, b) poor quality of the steel substrate. 
Figure 4 presents the microstructure of the zinc coating surface obtained by the scanning microscope Jeol JSM-6610LV. Furthermore, in the pictures are marked location of the measurements EDS spectra in zinc coating identified by EDX analysis areas. The analysis of chemical composition of the zinc coating surface are presented in Table 3.

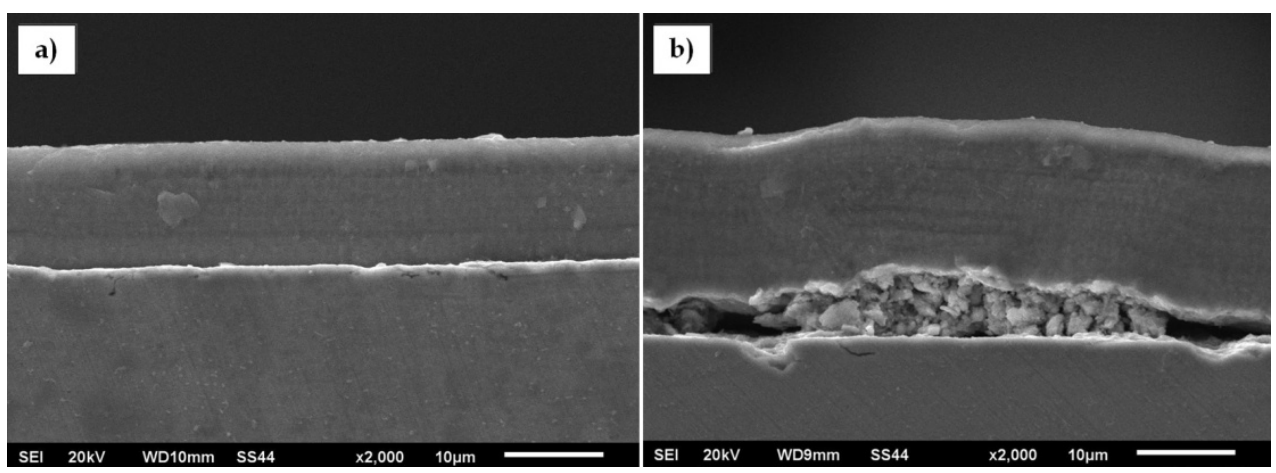

Fig. 4. Microstructure of zinc coating with: a) good, b) poor quality of the steel substrate.

Table 3. EDX-analysis of chemical composition of the surface in zinc coating (location of the measurements is marked in Fig. 5).

\begin{tabular}{|c|c|c|c|c|}
\hline & \multirow{3}{*}{ Element } & \multicolumn{3}{|c|}{ Weight [\%] } \\
\hline & & \multirow{2}{*}{$\begin{array}{c}\begin{array}{c}\text { Good quality of } \\
\text { the steel substrate }\end{array} \\
\text { Spectrum } 1\end{array}$} & \multicolumn{2}{|c|}{$\begin{array}{c}\text { Poor quality of the steel } \\
\text { substrate }\end{array}$} \\
\hline & & & Spectrum 1 & Spectrum 2 \\
\hline \multirow{10}{*}{$\begin{array}{l}\text { Zinc } \\
\text { coating }\end{array}$} & $\mathrm{C}$ & 17.05 & 6.33 & 13.56 \\
\hline & $\mathrm{O}$ & 9.56 & 4.77 & 5.86 \\
\hline & $\mathrm{Al}$ & - & 0.31 & 0.12 \\
\hline & $\mathrm{Si}$ & 0.26 & 0.73 & 0.53 \\
\hline & S & 1.98 & 0.27 & 0.96 \\
\hline & $\mathrm{Cr}$ & 1.00 & - & 0.47 \\
\hline & $\mathrm{Mn}$ & - & 1.66 & - \\
\hline & $\mathrm{Cl}$ & - & - & 0.23 \\
\hline & $\mathrm{Fe}$ & 0.45 & 83.12 & 0.48 \\
\hline & $\mathrm{Zn}$ & 69.70 & 2.81 & 77.79 \\
\hline
\end{tabular}


The X-ray phase analysis was conducted to identify the phase composition of the zinc coating. The results of the analysis are presented in Figure 5.
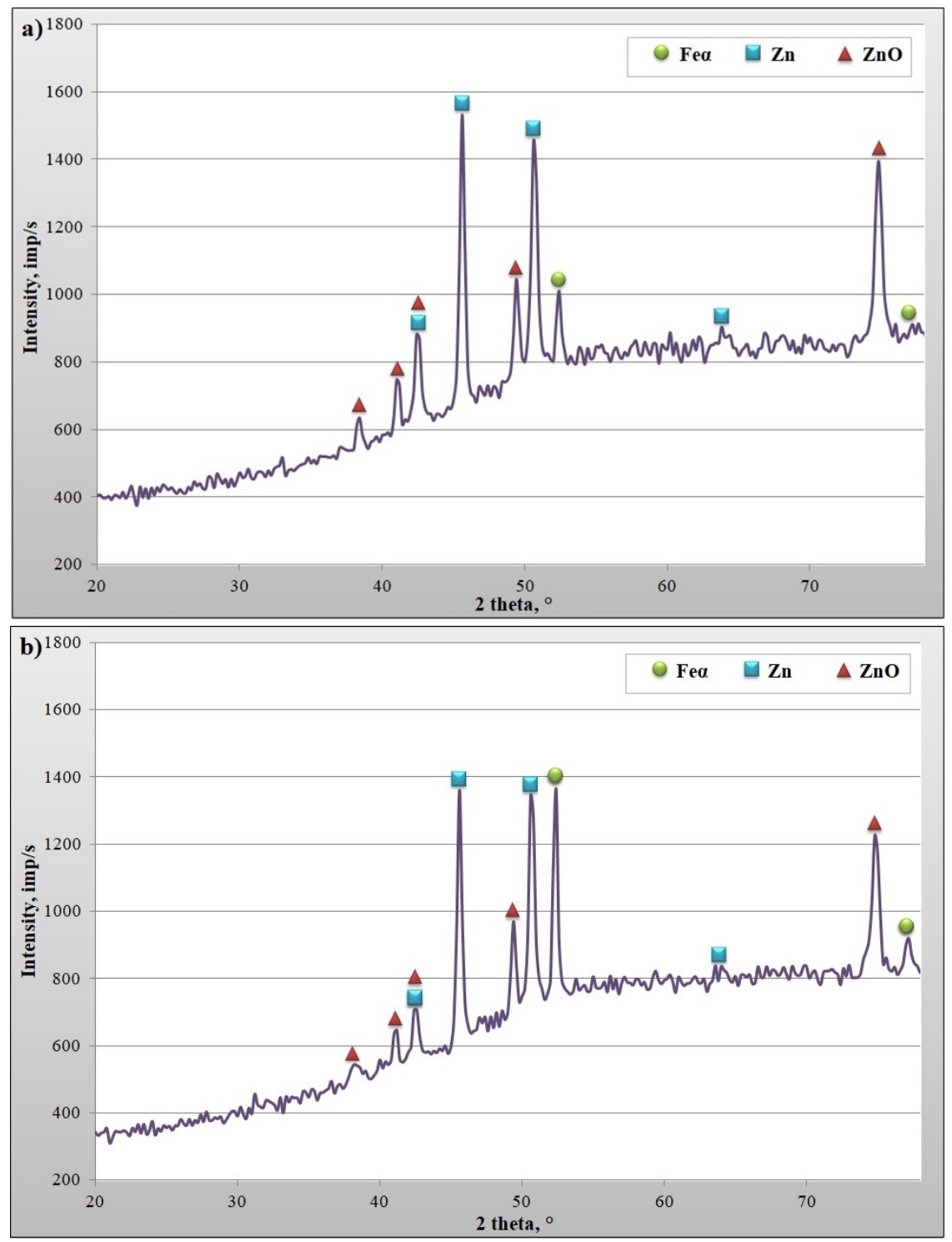

Fig. 5. Diffractogram of the zinc coating with: a) good, b) poor quality of the steel substrate.

The phase composition analysis for individual specimens revealed presence of the ferritic phase (cell parameters: $\mathrm{a}=\mathrm{b}=\mathrm{c}=0.286 \mathrm{~nm}, \alpha=\beta=\gamma=90^{\circ}$ ) which it is crystallizes in cubic cell. Additionally, analysis revealed presence of zinc crystallizes in hexagonal cell (cell parameters: $a=b=0.266 \mathrm{~nm}, \mathrm{c}=0.495 \mathrm{~nm}, \alpha=\beta=90^{\circ}, \gamma=120^{\circ}$ ) and zinc oxide crystallizes in hexagonal cell (cell parameters: $\mathrm{a}=\mathrm{b}=0.325 \mathrm{~nm}, \mathrm{c}=0.521 \mathrm{~nm}$, $\alpha=\beta=90^{\circ}, \gamma=120^{\circ}$ ). 


\section{Conclusion}

Steel galvanizing process is widely used in the automotive industry by means of a component protection method against corrosion. The galvanizing S500MC steel presented in this study is used for the production of truck chassises. As results from the conducted research, preparing the substrate before the galvanizing process is of great importance. Microstructural examinations have proven that the series of samples were subjected to a recrystallizing annealing process under different conditions. For this reason, the series of samples subjected to the test were characterized by a different thickness of oxides formed as a result of the heat treatment.

\section{References}

1. S. Rashmi, L. Elias, A.C. Hegde, JESTECH, 20, 3 (2017)

2. S. Ghaziof, W. Gao, Appl. Surf. Sci., 311 (2014)

3. X.G. Zhang, Corrosion and Electrochemistry of Zinc (Springer-Verlag, New York Inc., 6, 2013)

4. A. Amirudin, D. Thierry, Prog. Org. Coat., 28, 1 (1996)

5. V. Kuklik, J. Kudláček, Phenomena on galvanized coatings, Hot-Dip Galvanizing of Steel Structures $(67-92,2016)$

6. F. Simescu, H. Idrissi, Sci Technol Adv Mater., 9, 4 (2008)

7. N. Jantaping, C.A. Schuh, Y. Boonyongmaneerat, Surf. Coat. Technol., 329 (2017)

8. R. S. Lillard, C. Valot, M. A. Hill, P. D. Dickerson, R. J. Hanrahan, Corros. Sci., 60, 11 (2004)

9. M. Kobya, E. Demirbas, F. Ozyonar, G. Sirtbas, E. Gengec, Process Saf Environ Prot., 105 (2017)

10. K.A. Yasakau, I. Giner, C. Vree, O. Ozcan, R. Grothe, A. Oliveira, G. Grundmeier, M. G.S. Ferreira, M.L. Zheludkevich, Appl. Surf. Sci., 389 (2016)

11. Z.F. Lodhi, W.J. Hamer, J.M.C. Mol, H. Terryn, J.H.W. de Wit, Mater. Corros., 59, 4 (2008)

12. R. Oyyaravelu, P. Kuppan, N. Arivazhagan, J. Adv. Res., 7 (2016)

13. N. Wint, J. Leung, J.H. Sullivan, D.J. Penney, Y. Gao, Corros. Sci., 136 (2018)

14. R. Ulewicz, F. Novy, Journal of The Balkan Tribological Association, 22, 1147-1155 (2016)

15. N. Radek, J. Pietraszek, B. Antoszewski, Adv. Mat. Res.-Switz., 874, 29 (2014)

16. P. Szataniak, F. Novy, R. Ulewicz, $23^{\text {rd }}$ International Conference on Metallurgy And Materials (778-783, 2014).

17. T. Lipinski, A. Wach, $23^{\text {rd }}$ International Conference on Metallurgy And Materials (778-783, 2014). 